Dr. Hanan Abdel-Baqi Mohammad Khalil

\title{
The Effect of a Training Program Based on Task-Based Learning on Developing English Majors' Skill of Document Translation and Their Attitudes towards Translation Dr. Hanan Abdel-Baqi Mohammad Khalil \\ Lecturer of (Methods of TEFL), Col. of FL Misr University for Science \& Technology (MUST)
}

\begin{abstract}
The aim of this study was to investigate the effectiveness of a Task-Based Learning programin developing MUST English majors' skill of translatingdocuments and their attitudes towards translation. One experimental group of 32 thirdyear English Majors participated in the study.This group was tested on document translation and attitudes towards translation prior to the study. After that, the TBL program was taught by the researcher to this group. At the end of the experiment, the study group was posttested on document translation and attitudes towards translation.Results of the document translation test indicated that the training program was effective in developing the skill of translating documents among MUST English majors. Besides, there was a statistically significant difference between the mean score of the pre and post administration of the attitudes questionnaire in favor of the post administration.
\end{abstract}

Keywords

(Task- Based Learning, document translation,MUST English Majors) 


\section{مستلخص البحث باللغة العربية}

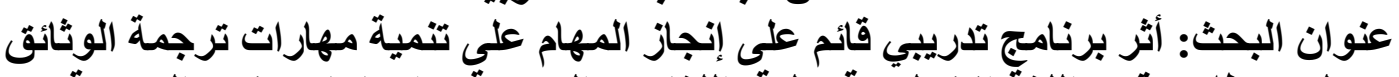

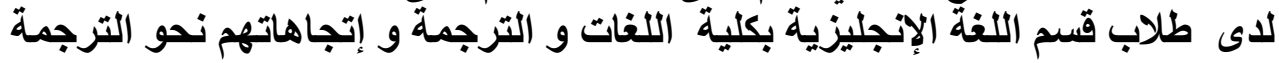

$$
\text { د. دنان عبد الباقى محمد خليل }
$$

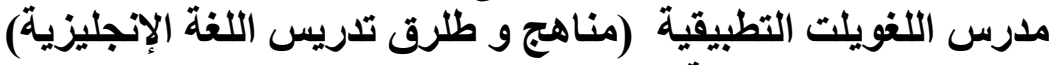

\section{بجامعة مصر للعلوم و التكنولئوجيا.}

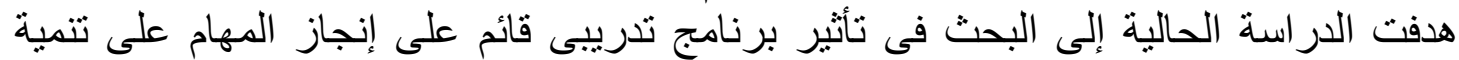

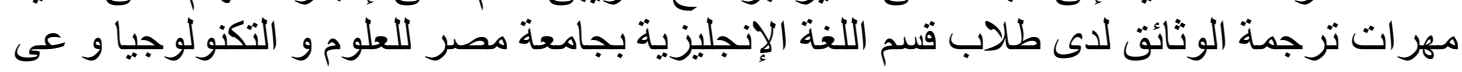

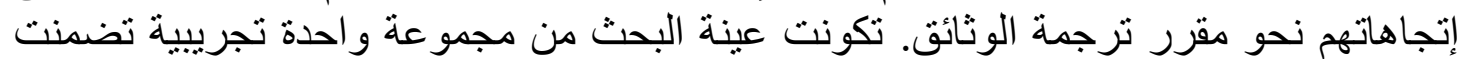

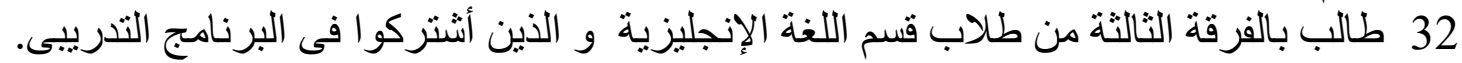

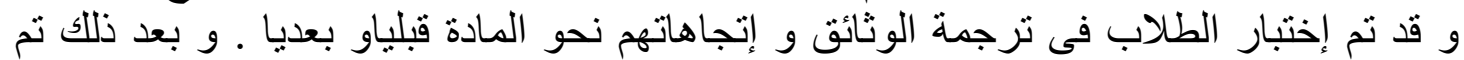

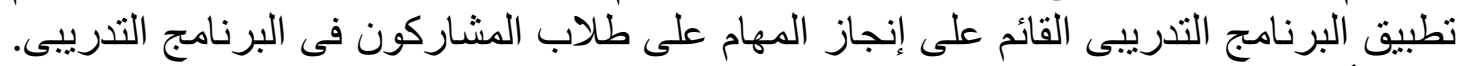

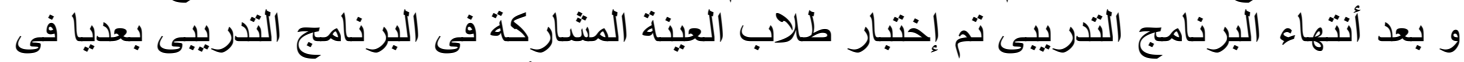

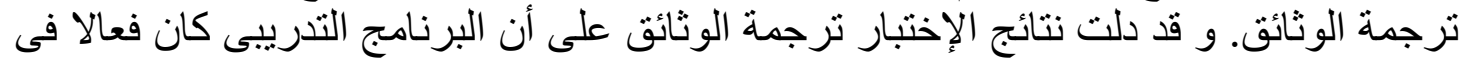

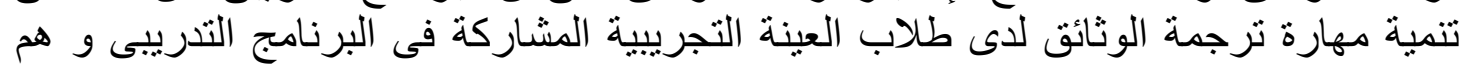

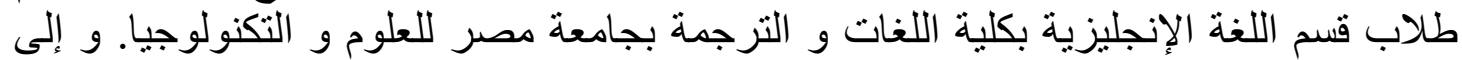

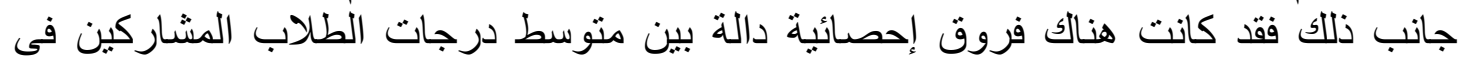

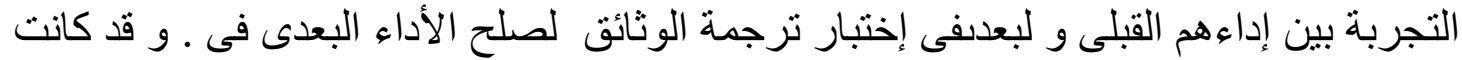

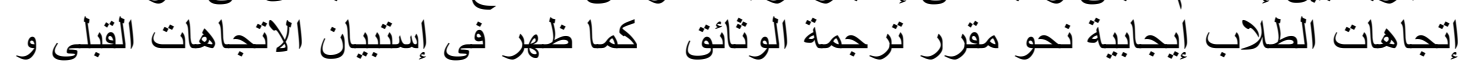

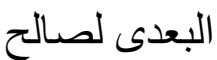
التطبيق البعدى للإستبيان.

الكلمات المفتاحية.( التعلم القائم على إنجاز المهان النهام , ترجمة الوثائق, طلاب قسم اللغة الإنجليزية بجامعة مصر للعلوم و التكنولوجيا) 


\section{Dr. Hanan Abdel-Baqi Mohammad Khalil}

\section{Introduction}

In the globalization world, English language has becomemore important than before This, in turn, requires the translation of different types of documents from and into English for a lot of purposes. These purposes include but are not limited to, legal, commercial, social, and educational ones (Abbadi, 2008; Al Naggar, 2011)

In recognition of the importance of the translation of documents in the area of commerce, for example the Federal Trade Commission(2016) required that all non- English language documents should be translated into English for better understanding. In addition, all law firms and recruitment agents that work in international locationsare requiredto hire a certified/ or legal translator to help them with all of their official documents to be translated.In the area of social affairs, the importance of translation of documents is also emphasized. These documents include marriage and divorce contracts, birth certificates, and educational documents such as certificates of graduation, grade sheets, MA or PHD certificates, etc. ( Rodriguez-Castro; Bassnett, 2014; Galal- manas, 2013).

Despite the importance of document translation in the globalization world, the researcher noticed that English majors at Misr University for Science \& Technology encounter many difficulties in translation in general and document translation in particular. This study, therefore, is an attempt to find a solution to this problem

\section{The Pilot Study}

Beforeconducting the experimental study, the researcher conducted pilot study with the experimental group participants to identify their practical problems in translation. The results of this pilotstudy revealed that:

1) Allthe participants did not receive direct training on the translation of documents;

2) About $80 \%$ of the participants find problems in understanding the meaning of the original documents and cannot differentiate the different types of documents.

3) Allthe participants were consider translating documents as a thorny problem.

4) Allthe participants have encountered lexical-semantic, rhetorical, and cultural problems in translation; and

5) All of them do not enjoy translating documents fromArabic into English and vice versa. 
The Effect of a Training Program Based on Task-Based Learning on Developing English Majors' Skill of Document Translation and Their Attitudes towards Translation

In light of the previously-mentioned pilot results, it is evident that the participants are in need of a program to develop their document translation skill and attitudes towards translation.

\section{Context of the Problem}

English majors who have registered the course (Translation of documents) encoded as (Trans 301) have insufficient information about the document translation skill that should be adopted to be efficient translators of documents. They also mentioned that they have not received any kind or direct instruction or subject matter on translating documents before.. So, there was an urgent need for a trainingprogram on translating documents in a more real and practical, and strategic approach based on (TBLT) to English majors at MUST,

\section{Statement of the Problem}

English majors at MUST lack the skill of translating documents. Most of them encounter problems in understanding the meaning of the original document. Most of them cannot transfer the meaning of the source text into the equivalent in the target language. All of them consider translating official papers; documents as a thorny problem. All of them donot know the different types of documents, and cannot mention the purposes of translating documents.

\section{Questions of the Study}

The current study attempted to answer the following questions:

1) To what extent was a task-based program effective indeveloping MUST English majors' skill of document translation?

2) To what extent was a task-based program effective in developing MUST English Majors' attitudes towards translation?

\section{Hypotheses of the Study}

This study attempted to test the following hypotheses:

1) There is a statistically significant difference between the mean scores of the experimental group in the pre and postadministrations of the document translation test in favour of the post administration. 
2) There is a statistically significant difference between the mean scores of the experimental group in pre and post administrations of the attitudes questionnaire in favour of the postadministration.

\section{Literature Review}

The following section sheds light on the main variables of the current study. The variables of the current study upon which the training program is based are the training program based on task-based learning as an independent variable and developing skill of document translation as a dependant variable.

\section{Definition of Document Translation}

This type of translation refers mainly to the transfer of translation of official papers from one language (Source Language) SL into another (Target Language) TL. It is a special type of translation which is always required by governmental agencies, embassies or foundations which offer some scholarships for Egyptian graduates or academic grants offered by foreign universities such as the AUC in Egypt or any other English universities such as Oxford or Cambridge universities or any other wellknown universities. Some international schools or universities in Egypt ask for certified translated certificates of birth, graduation, grade sheets to be written in English despite of the fact that they are mainly given in Arabic from the governmental universities, civil registry office or any other official governmental agent.

The word 'document' is defined according to Webster (2016) as an

'Official paper relied on as the basis; proof, evidence, or support of some event".

The operational definition of document translation is "Helping English majors at MUST to acquire some tasks to enable them to translate efficiently three main types of documents; certificates, commercial contracts, and legal documents through a number of sessions of a training program based on TBL.

\section{Importance of Document Translation}

The translation of documents is studied as a core course in most Faculties of Foreign Languages and Translation at the English departments in almost all the governmental and private universities in Egypt. At MUST, English majors must complete their credit hours at the English department by studying the course ' Translation of Documents' coded as Trans 301 which is considered a core and an essential course 
The Effect of a Training Program Based on Task-Based Learning on Developing English Majors' Skill of Document Translation and Their Attitudes towards Translation

among some other courses in written translation such as translation of specialized topics, Linguistic Problems in Translation, and other oral translation courses such as Dubbing, Interpretation I; II; III; Consecutive I; II; III to prepare the graduates to be competent in most types of translation to have a distinguished job opportunity after graduation.

So this type of document translation is a practical application of both linguistic features, andknowledge of official fixed legal, commercial, educational expressions in both Arabic and their equivalents in English. (Gotti, 2016; McAuliffe, 2016; Stolze, 2013; Biel, 2009).

" The outcome of this type of specialized translation include translating documents from the Source language (SL) to the Target Language (TL) with the same official content that should be valid and must have the same effect as the documents in the source language'. ( Sandrini, 2009)

\section{Types of Documents}

Thereare many types of documents, among those there are essential three types of documents that are urgently needed for the purposes of travel, study, marriage, immigration, obtaining property or any other purposes. Among those three types are the official certificates of all types; birth, graduation,

marriage, divorce, death, and, commercial contacts, legal documents. Each one of those documents has many types also, So, one of the prerequisites of graduation of many English majors at departments of English. Needing a document to be translated in a limited time from the SL to the TL is not an easy job. It needs the knowledge of the professional equivalents in both language. Otherwise, all this job can be rejected, and can cause some problems to the translator especially if it is his only job.

\section{Certificates}

According to Webster (2016), the term " certificate" is defined as a document containing a containing a certified statement which proves the truth of requirements of and may be required in a in a specific field. From another perspective, the certificate can be defined as a document evidencing ownership or debt.

This type of documents is required officially to be submitted as an evidence to prove a social, educational or any other e vent. They are usually submitted to official authorities as a proof. They are usually submitted to schools, universities, or sometimes required in courts.Types of certificates are too many, but the most important among those are: birth certificate, marriage certificate, divorce certificate, grade sheets, 


\section{Dr. Hanan Abdel-Baqi Mohammad Khalil}

conference attendance certificates, appreciation certificate, MA or PHD certificates, etc.

\section{Commercial Contracts}

Contracts are agreements between two or more parties to exchange performances in a given situation for a specific purpose. Those contracts are considered as "operative documents" (Tiersma, 1999) in which the relationship between the partiesis symmetrical, as both parties have something of interest to the other party (commission, marketing, buying, selling, or any other consideration etc). Contract provision have legal significance under which the contracting parties perform or settle any arising dispute.

(Pryal; Jack, 2010). Contracts can be drafted for many purposes, such as for the sale of goods, employment agreements, etc. (Orts LIopis, 2009). Contracts can be drafted in a number of different ways, but in most cases they share similar format of the following fundamental components: 1) A heading and introductory paragraph to the contract; 2) Glossary of defined terms; 3) section of rights and obligations; 4) Section of general provisions; 5) Signatures Lines. ( Burnham, 2003; Back, 2018)

In his book "' Translation of Commercial Contracts', Al Morshedy (2007) introduced three basic phases in translation in general and the translation of commercial contracts in particular:

1. Receptive phase:

In which the translator or the English major receives and understands the commercial text, In this phase, the translator is just a receiver.

2. Switching phase:

Where the translator attempts to find some linguistic equivalents and the appropriate fixed expressions from SL to TL.

3. Productive phase:

In this phase the translator produces an appropriate version of the text in the SL into the TL.

The texts of contracts can be classified into three types: directive, commissive, and constitutive creating or modifying legal relationships between parties (Zedan, 2015).Contracts are considered one of the most difficult documents to translate. Provided it is impossible to apply unilaterally national law, translators should understand which legal system that should regulate the specific case.Linguistically, this kind of text seems to be characterized by long sentences with a complex structure as a mean to cover the conditions and possibilities in which such an event may occur, adding to that there are exceptions to be taken in account that concur in making sentences even more complex. (Calvijo, 2013) 
The Effect of a Training Program Based on Task-Based Learning on Developing English Majors' Skill of Document Translation and Their Attitudes towards Translation

\section{Legal Documents}

Translating legal documents can be defined as the process of transferring some legal content (usually official) from one language to another ( McAuliffe, 2016). It is considered as a special type of translation which takes place in the mechanism of law

( Sarcevic, 2000).It is also classified as a technical type of translation not only because of the culture- laden nature of legal discourse, but also because of the need for formal correspondence between equally authoritative versions of the same text. (Gotti, 2016).

" The outcome of this type of specialized translation form documents in the target language with the same legal validity and effect as the documents in the same language",

( Sandrini, 2009) .

Hatim; Shunnaq; Buckley (1995)introduced a practical guide in both the legal translation, and the translation of commercial contracts especially from Arabic into English. Translating legal documents could be of Judicial purposes, that is where the original source language texts( e.g. samples of memorandum) can be used in court proceedings as part of documentary evidence for an event or crime. Those type of translations usually involve an informative, as well as descriptive function, and may include ordinary texts, such as business or personal correspondence, witness statements, and expert reports, etc. Such texts are not often written in legal language by legal professionals, but enter the sphere of legal translation due to the special requirements of legal communication.

The process of translating legal documents requires the knowledge of both the legal terminology and the nature of law making it necessary for the translator to master both.

( Gotti, 2016; Cao, 2014).

Legal translator must be fully linguistically proficient in both the source and target language( Shiflett, 2012; Schaffner, 2014; Gotti, 2016).Translators of legal documents developed their particular linguistic; features; lexical, syntactic, and pragmatic to meet the demands of law and its applications. Themost typical problems in legal translation are mainly due to terminological, collocation, punctuation, and grammatical errors in both native and foreign languages( Cao, 2014; 2007; Matulewska; Gortych-Michalak, 2014).

\section{Task Based Learning (TBL)}

There was a lot of emphasis on both the importance of the role of TBL in the field of learning and teaching of English as a FL by many educators and writers (Ellis, 2009; 2013; Martin, 2015). In this perspective Both 


\section{Dr. Hanan Abdel-Baqi Mohammad Khalil}

(Willis ,2001; Ellis ,2003; Klapper ,2003; Snachez, 2004; Nunan ,2004; Oxford ,2006) introduced the term "task" as a word refers to the special kind of activities carried out in the EFL classroom and involves the learner in understanding, manipulating, producing or interacting in the target language while their attention is focused on mobilizing their grammatical and lexical knowledge in order to express meaning, and in which the intention is to convey the exact lexical meaning rather than to manipulate form. It is a structured instructional plan that requires learners to move toward an objective or outcome using particular working procedures or processes. Also, Dammacco (2009) defined a task as "an activity that is deductive rather than inductive, with emphasis on the process or experience it is driven by an underlying end goal".

This is emphasized by Snachez (2004), Mclaughlin (2001), and Lee (2000) as they agreed upon the idea that TBL is an approach to English language learning in which learners learn by doing tasks that achieve the goal of learner-centered approach which focuses on learners' involvement, participation, interaction, and communication.

Nunan (2004) stated that TBL is "an approach to language teaching organized around tasks rather than language structures". Also, Kavaliauskiene (2005) agrees with Nunan's definition by saying that TBLA is "a process of language acquisition through solving a problem or doing a task without concentrating on language features".

Ellis $(2009$; 2013) explained that it is essential in each definition there is a focus on the importance of sharing information and knowledge among learners in order to achieve a specific goal and outcome which provide learners with the motivation to engage in the task and work independently. Also, most of these definitions focus on the communication of meaning as learners are free to use whatever language they want in order to convey their intended meaning and to sustain the interaction.

Concerning the definitions presented above, it is clear that a task is goal oriented as all tasks have an outcome that must be achieved. It also helps learners practice relevant skills. So, after knowing what is meant by the word task; it can be concluded that TBLA has been considered as a classroom event in which learners have an active role.

TBL is considered an approach adopted in English language learning in which learners are involved in doing tasks. The emphasis is on the task to be accomplished as it helps the learners to be in real life situations. Some educators such as (Willis ,2001; Klapper ,2003; Nunan ,2004 ) agreed that tasks for a communicative purpose in order to accomplish a specific purpose. 
The Effect of a Training Program Based on Task-Based Learning on Developing English Majors' Skill of Document Translation and Their Attitudes towards Translation

In the current study, TBL is specifically defined as an approach adopted by MUST English Majors to develop the skill of document translation by accomplishing a number of tasks in translation from the SL to the TL in a more professional and near to be certified way.

Those tasks help in motivating MUST English Majors to achieve an efficient performance in translating some specific types of documents ( i.e. certificates; commercial documents ; legal documents. Those tasks could also help them managing the translation processes, communicating effectively, creating a more efficient learning atmosphere, and making the learning more student -centered with the role of the lecturer as monitoring them.

\section{TBL Framework}

The TBL has various designs that have been suggested by many researchers and methodologists. Willis's model $(1996 ; 2011)$ supported by Ellis(2013 ; Salimi, 2015) is one of the most common used designs. The task sequence of any session follows three basic phases:

\section{Pre-Task}

In which the teacher or lecturer introduces the topic of the session and the tasks involved in itwhere the EFL learners learn the fixed expressions, linguistic chunks, specialized terminology. In this phase, the aim is to facilitating tasks conducted before the primary tasks in order to motivate the EFL students and raise their own consciousness by activating topicrelated words and expressions, lexical and grammatical forms.

\section{Task-Cycle/ During Task}

This is the main task-phase in which students are exposed to different language features and use the target language to accomplish task requirement.

\section{Post-Task}

This phase aims primarily to check for accuracy, linguistic correctness, correctness of using the suitable content of the TL. It consists of two essential phases; analysis, and practice.

\section{Rationale for Using TBL in Teaching the Translation of Documents}

Because of the few studies that deal with translating the documents, the traditional methods and approaches used generally in translation and specifically in the translation of documents they need to be modified so as to involve additional and more professional tasks and competences into the course content implementing the TBL methodology. ( Kasap, 2005; Kavaliauskiene, 2005). 
From this perspective, (Aurelia, 2012) recommended that the textbooks of professional translation such as the translation of documents, legal translation, conference translation, and its other types should include practice tasks that focus on both specific vocabulary and on the grammar structures and functional language. Task-oriented activities increase self confidence and empowering English majors specialized in professional translation to meet the requirements of professional training and real life activities. ( Beil, 2011).

\section{Benefits of TBL in Teaching English as a FL, and Document Translation}

There are various benefits for using tasks in the EFL classrooms. Ellis (2003) mentioned that TBL serves as the most obvious means in using language easily and effectively for communicating inside the classroom. It provides learners with the motivation to improve and build on whatever language they already have.

Furthermore, using tasks in the FL classroom evolved from Willis's view (2001) which explained how tasks provide the stimuli for learners to take part in complete interactions inside the classroom. He states "tasks remove the teacher domination, and learners get chances to open and close conversations, to interact naturally, to interrupt and challenge, to ask people to do things and to check that they have been done. Much of this will involve composing in real time. The resulting interaction is far more likely to lead to increased fluency and natural acquisition".

Swan (2005) points out that tasks can certainly be structured to promote more complex and accurate interaction, and this aspect of task design and implementation has generated much valuable research. Nunan (2005) stated that among the benefits of TBL the increased student participation by making specific lesson goals more evident through movement towards and/or success of task completion and providing ongoing assessment.

\section{Experimental Related Studies in Translation Issues}

(Farahaty,2016) conducted a study which attempted to clarify the common lexical difficulties between English and Arabic legal texts and documents was the study of which analyzed an authentic legal corpus of English/ Arabic legal authentic texts and documents. The analysis reached to the fact that there are many difficulties the legal translators face when translating from SL to $\mathrm{Tl}$ texts because of a considerable number of cultural- pond terms, linguistic-based and system -based terminology.

Another study was conducted by Al-aqad(2014) analyzed five different forms of marriage contracts translated by different native translators in Arabic into English explored the cultural and linguistic equivalence in 
The Effect of a Training Program Based on Task-Based Learning on Developing English Majors' Skill of Document Translation and Their Attitudes towards Translation

Arabic and English legal translation aspects.. The study proved that the translation of both legal texts and documents differs from other types of translation in two basic components: the legal system and the terms associated with each system.

While Noman ( 2014) conducted an analysis of the register of US Constitution, and its Arabic translation aiming to identify the lexical and syntactic problems of getting the equivalence in translating the US constitution into Arabic. The findings of the analysis showed that language of the US constitution is primarily very complex as the text features are absolutely indicative and declarative mode clauses. It also explained that the language of the US constitution is mainly characterized by the lexical repetition, lack of conjunctive and cohesive relations, modal verbs, syntactic complexity, and the need of applying the legislative rules.

Al-Kholy (2013) investigated the stylistic features of translating the authentic Arabic legal texts and documents into English. Certified translators of the Egyptian constitution and laws' translations were analyzed qualitatively and compared in terms of their lexical, syntactic, and textual features. The study concluded that despite of the fact that both Arabic and English are different in their linguistic systems, and cultural background due to their directive function, similarities between Arabic and English in their texts some features in their legal texts in their lexicon and syntax are more than their differences.

\section{Experimental Related Studies in Using TBL in TEFL}

A study was conducted by El Saeed (2015) aimed to investigate the effect of using task-based learning on developing $6^{\text {th }}$ of Oct., student teachers' teaching performance in the English language. The study proved the positive effect of using task-based learning on enhancing the student teachers' teaching performance in teaching EFL.

A group of (20) $3^{\text {rd }}$ year student teachers participated in the study, Faculty of education.

Who were randomly selected from October 6 University as one experimental group. They received training program based on using taskbased learning to develop their teaching performance. A pre/post observation sheet was designed to determine the effect of the TBL approach and used before and after conducting the experiment Findings of the study proved that adopting TBL in the training program could help in developing the teaching performance of the participants through the 


\section{Dr. Hanan Abdel-Baqi Mohammad Khalil}

statistical differences between the pre/ and post administration of the observation sheet.

Liu \& Liu (2011) aimed at exploring the influence of the TBL teaching on vocational college students in the course of Auto Electronic Control Technology. In order to achieve this aim, this research, based on the principles of universality and exploitability of creativity, takes teaching experiments. The result is that using TBL based courses enabled the study group to learn during the process of solving problems and therefore appeals more to students. In addition, it was clear that teachers' teaching methods had a positive influence on the improvement of students' learning interest, which, as a non-intelligent factor, has a direct effect on students' learning quality and creativity.

Kabesh (2010) conducted a research aiming at developing the required skills of both reading comprehension and writing for upper primary stage students through using of the TBL based on the multiple intelligence theory. A group of fifty four sixth year primary school students were randomly selected. Students of the experimental group received training through the TBL Based program while students in the control group received regular instruction. The study's results provided support for the hypotheses, i.e. the TBLA based on MI theory was effective in developing the necessary reading and writing skills among the experimental group students. Moreover, adopting the TBL based on the multiple intelligences theory and integrating reading and writing in teaching the novel helped students improve their writing and reading performance skills.

Murad (2009) aimed at investigating the effect of a TBL teaching program on

developing the speaking skills of Palestinian secondary students and their attitudes towards English. The participants in the study were (91) eleventh grade students, 37 boys and 54 girls, from Bueina- Nujidat and Tamra High Schools. A TBL teaching program was designed and used by the researcher for the experimental group. The findings

proved that using TBL teaching program enhanced significantly the speaking skill of the students of the experimental group and positively affected their attitudes towards English. Also other results showed that the TBL-based program improved the girls' speaking skills more than the boys in the experimental group. 
The Effect of a Training Program Based on Task-Based Learning on Developing English Majors' Skill of Document Translation and Their Attitudes towards Translation

Ruso's study (2007) investigated finding solutions to certain problems such as poor learners' motivation through using TBL. The study group consisted of (55) EFL students from two English classrooms and the researcher, a Turkish teacher, participated in the study. The findings of the study reveal that implementing a TBL in EFL classes created variety of learning opportunities for the study group. Moreover it could enhance their learning, since TBL tasks encouraged the EFL students involvement and lead to significant improvements regarding their language performance. The research participants suggest that they do not like teacher-directed lessons where they cannot find enough opportunities to express themselves in the target language.

From the above studies, it was clear that TBL proved to be effective in developing so many language skills and the teaching performance of student teachers at faculties of education. It could develop listening, speaking, reading, and writing because it depends primarily on accomplishing activities inside the classroom, and student-centered learning approach, raising self- dependence, self-confidence, and learning autonomy of the EFL learners. It was also used to develop the acquisition of other foreign languages such as Spanish.

Depending on those findings, and because the researcher of the current study could not find any related studies that used TBL in teaching the skill of document translation, the TBL was adopted by the current study with an aim of developing the skill of document translation of MUST English Majors, and raising their positive attitude towards translation in general, and the translation of documents in particular.

\section{Method}

\section{Design of the Study}

The current study used a pre test/ post test one study group Quasiexperimental design. The participants of the study were selected intentionallyby the researcher from third year, MUST English majors because she is a staff member at the English department, college of FL at MUST.

\section{Participants of the Study}

The study group consisted ofthirty two3rd English majors at Misr University for Science \& Technology (MUST), who registered the course" Translation of Documents" coded as Trans 301 in Fall 2018/ 2019 semester. 


\section{Dr. Hanan Abdel-Baqi Mohammad Khalil}

\section{Delimitations of the Current Study}

The current study is limited to:

1. A group of $3^{\text {rd }}$ year English majors (32) at MUST who registered the course

(Trans 301); Translation of Documents at the English department at Fall 2018/2019 semester.

2. Only three types of documents; certificates, commercial contracts, and legal documents that are included in the training program.

3. Adopting the TBL as an effective approach for training on the skill of document translation.

\section{Instruments of the Study}

The study used two instruments: a pre/post document translation Test, and an attitude questionnaire.

\section{Translation of documents Test}

The pre/ postTranslation of Documents test was designed and used by the researcher to obtain the quantitative data of the effect of the training program based on TBL.The Translation of Documents Test was administered to $3^{\text {rd }} \& 4^{\text {th }}$ English majors at MUST consisted of five evaluation tasks.It was designed primarily to assess the study group's efficiencyin translating the three basic types of documents; the certificates, commercial contracts, and legal documents, translation of the names of the courses they study; core and elective. The total score of the test was seventy five. Each of the five evaluation tasks was scored out of fifteen marks. See Appendix 1.

\section{Validity of the Translation of Documents Test}

To ensure the validity of thepre/ post translation of documents test, the first version of the test was presented to a panel of jury members. The modifications that they suggested were put into consideration. The $1^{\text {st }}$ version of the test (Appendix: 2) includedsix main tasks. The jury suggested deleting one of the tasks and changing some questions that seemed to be simple for $3^{\text {rd }} \& 4^{\text {th }}$ year students, The researcher considered their suggestions and designed the modified version of the test, version 2 , Appendix 2 which included five evaluation tasks only instead of six and modified some questions so as to be efficient and understood. Then, the test was administered pre/ postto the participants of the study.

\section{Reliability of the Translation of Documents Test}

The final version of the test was administered to (30) $3^{\text {rd }} \& 4^{\text {tht }}$ year English majors at MUST( not included in the main treatment of the study) . Cronback's Alpha (Pane, 1997) was used to calculate the reliability coefficient of the test. The calculated coefficient was 0.86 . Thus, the 
The Effect of a Training Program Based on Task-Based Learning on Developing English Majors' Skill of Document Translation and Their Attitudes towards Translation

reading efficiency test was reliable to be used in assessing the efficiency of the reading strategies of $1^{\text {st }}$ year English majors at MUST.

\section{The Attitude Questionnaire}

This instrument was prepared and conducted by the researcher to show the study group's attitudes towards translation in general and the training program based on task-based learning. The questionnaire consisted of ten statements.These statements were rated by students on a five point Likert-scale (see Appendix 2). This questionnaire was validated by a jury of 3 assistant professors of Translation, TEFL, and AppliedLinuistics. They revised the questionnaire in terms of wording and attitudinal appropriateness. Then, using a test-retest method, reliability was assessed using Cronbach's alpha coefficients and intraclass correlation coefficients. Item-to-scale correlation was assessed using Spearman's rank correlations $(\rho)$ between scale scores and their constituent items. The reliability coefficient of the scale using Cronbach Alpha was $(\alpha=0.76)$ which is anappropriate value.

\section{Scoring}

There were no model answers to the pre/posttranslation of documents tasks. A certain translation task may have more than one answer and accordingly the study group's responses may vary. Hence, the five translation tasks were scored according to the holistic approach.To achieve the objectivityof scoring, two examiners; the researcher and another examiner) graded the students' document translation in terms of these criteria: (a) conveying the sense of the document, (b) culture transference, and (c) use of accurate expressions, grammar and mechanics. It was put into consideration that the two examiners were equal in experience and qualifications. The inter-rater reliability between the two raters was calculated was $(0.801)$. The test was scored out of 75 marks; 15 for each evaluation task.

\section{The Treatment}

\section{The Main Objectives of the Current study}

By the end of the training program Based on TBL, English majors will be able to:

- Translate the three types of documents; certificates, commercial contracts, and legal documents from Arabic to English and vice versa efficiently;

- Accomplish the tasks on the translation of documents accurately in each session of the program;

- Co-operate with their peers to finish the required tasks; 
- use the online sourcesavailable at MUST to accomplish their translation tasks;

- use the fixed expressions, specialized contexts, and the correct linguistic contexts in translating the target documents from SL into TL;

- Compare their own translations with some certified translations of the same documents; and

- evaluate some translated documents according to the tasks they acquired from the training program.

- The Training program based on TBL included twelve sessions.

IntroductorySession

1. Objectives of the session

By the end of this session, English majors will be able to:

- Write the definition of the term' document' correctly on the board;

- mention ten types of documents;

- discuss ten types of certificates with their peers; and

- write correctly both the core and elective courses they study at MUSt on

the white board.

\section{Pre-Task}

The researcher asked a few questions about the content of the session to activate the students and prepare them for the session and test their prior knowledge.

The researcher introduced the basic definition of the terms "document, legal document, certificate'".

\section{During - Task}

The researcher introduced thepurposes of translating the documents. She gave examples of different fixed expressions, linguistic contexts, grammatical structures needed for translating documents in general.. Then, the researcher introduced the three types of documents that should be studied in details; certificates, legal documents \& commercial contracts in brief.

\section{Post-Task}

The researcher gave English majorssome of theauthentic documents to help the participants to be aware of such documents and what do they look like.

\section{Evaluation}

By the end of the session, the researcher asked the participants to try to translate a birth certificate as an attempt to prepare them for the next session. 


\section{Results and Discussion}

The following section discusses the results of the Translation of Documents test and supported by the relevant responsesfrom the pilot study achieved from the semi-structured interview.

\section{Results}

\section{Hypothesis One}

"There is a statistically significant difference between the mean scores of the experimental group in the pre / postadministrations of the overall document translation test and its three components in favour of the post administration of the test'.

\section{Figure 1: Descriptive Statistics of the Pre/Post Translation of} Documents

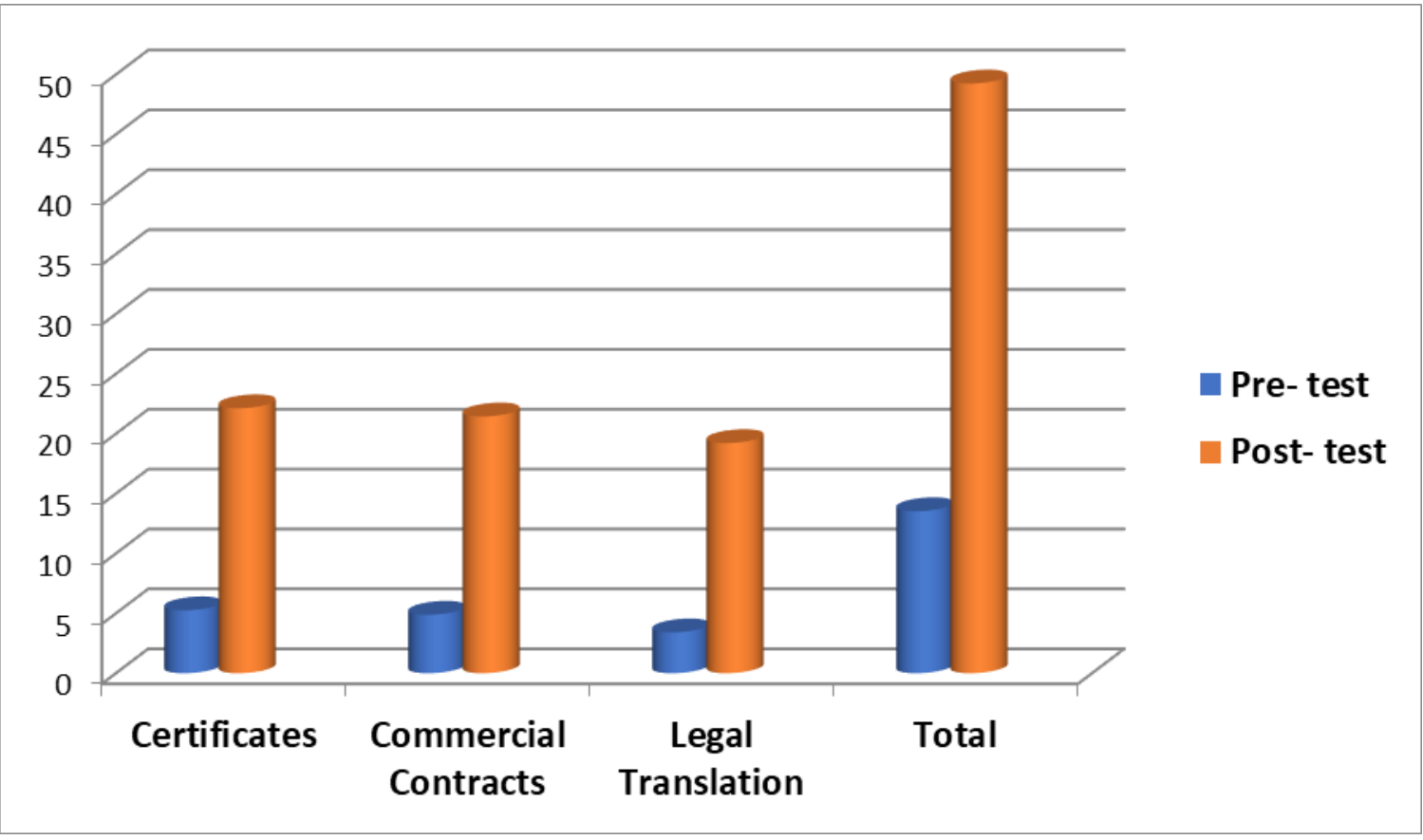

From Figure (1), it is evident that there are graphical differences between the students' scores in both the overall and each of the tasks in the translation of documents test and its three parts;certificates, commercial contracts, and legal documents. Their mean scores in the post test were higher than those of the post test.The following section deals with verifying the current study's hypotheses. 
Dr. Hanan Abdel-Baqi Mohammad Khalil

Table (1): The Mean Scores of the Pre /Post-test in the Overall Translation of Documents Test

\begin{tabular}{|l|l|l|l|l|l|l|}
\hline Implementation & $\mathrm{N}$ & Mean & $\begin{array}{l}\text { Std. } \\
\text { Deviation. }\end{array}$ & D.F & $\begin{array}{l}\text { t-test } \\
\text { Value }\end{array}$ & Sig. \\
\hline post test & 32 & 19.22 & 2.33 & 31 & 30.75 & $(0.05)$ \\
\hline pre test & 32 & 3.41 & 1.26 & 31 &
\end{tabular}

From table (1), it is clear that the $t$ value is (30.75) which is considered a high value, with a standard derivation of (31), and a significance of (0.05) of the one tailed test. This proved that there was a real statistical difference among the mean scores of the study group in the pre/ post administration of the overall translation of documents test in favor of the post administration of the test with the greater mean scores. So, the first hypothesis was verified. The following are the results of the three components of the translation of documents test.

Table (2) TheMean Scores of the Pre /PostTranslation of Certificates

\begin{tabular}{|l|l|l|l|l|l|l|}
\hline Implementation & $\mathrm{N}$ & Mean & $\begin{array}{l}\text { Std. } \\
\text { Deviation. }\end{array}$ & D.F & $\begin{array}{l}\text { t-test } \\
\text { Value }\end{array}$ & Sig \\
\hline post test & 32 & 22.13 & 2.12 & 31 & 43.74 & $(0.05)$ \\
\hline pre test & 32 & 5.25 & 1.41 & 31 & 4 \\
\hline
\end{tabular}

Table (2) reveals that the t value was calculated as 43.74 which is higher than the tcalculated value (1.69). This reflects that there is a true difference between the study group 's mean scores in the pre/ post administrations of the translation of certificates component test in favor of the pre/ post administration in the overall scores and the scores of the parts of the test. test shows the significance level of the mean scores of the study group in the pre/ post test .

Table (3) The Mean Scores of the pre / posttest in Translation of Commercial Contracts

\begin{tabular}{|l|l|l|l|l|l|l|}
\hline Implementation & $\mathrm{N}$ & Mean & $\begin{array}{l}\text { Std. } \\
\text { Deviation. }\end{array}$ & D.F & $\begin{array}{l}\text { t-test } \\
\text { Value }\end{array}$ & Sig \\
\hline post test & 32 & 21.44 & 2.51 & 31 & 32.14 & $(0.05)$ \\
\hline pre test & 32 & 4.88 & 1.38 & 31 & 32.14 \\
\hline
\end{tabular}


It is evident from table (2) that the calculated $\boldsymbol{t}$ value was 32.14 which was higher than the $t$ calculated one $(1,69)$. This reflects that there is a true difference between the study group's mean scores in the pre/ post administrations of commercial contracts in favor of the post administrations.

Table (4) The Mean Scores of the pre / posttest in the translation of LegalDocuments

\begin{tabular}{|l|l|l|l|l|l|l|}
\hline Implementation & $\mathrm{N}$ & Mean & $\begin{array}{l}\text { Std. } \\
\text { Deviation. }\end{array}$ & D.F & $\begin{array}{l}\text { t-test } \\
\text { Value }\end{array}$ & Sig. \\
\hline post test & 32 & 19.22 & 2.33 & 31 & 30.75 & $(0.05)$ \\
\hline pre test & 32 & 3.41 & 1.26 & 31 & \\
\hline
\end{tabular}

It is evident from table (4) that the calculated $t$ value was 30.75 which was higher than the $t$ calculated one $(1,26)$. This reflects that there is a true difference between the study group's mean scores in the pre/ post administrations of translation of commercial contracts in favor of the post administration of the test.

Table (5) The Effect Size of the Overall Mean Scores of the Study Group in the Pre/ post Translation of Documents Test

\begin{tabular}{|c|l|l|l|l|}
\hline $\begin{array}{l}\text { Sub- Skills } \\
\text { Translation of documents test }\end{array}$ & $\begin{array}{l}\text { t-test } \\
\text { Value }\end{array}$ & N & $\begin{array}{l}\text { Effect } \\
\text { Size (d) }\end{array}$ & $\begin{array}{l}\text { Practical } \\
\text { Significance }\end{array}$ \\
\hline Certificates & 43.74 & 32 & 7.73 & Educationally Important \\
\hline Commercial Contracts & 32.14 & 32 & 5.68 & Educationally Important \\
\hline Legal Translation & 30.75 & 32 & 5.43 & Educationally Important \\
\hline Total & 47.69 & 32 & 8.43 & Educationally Important \\
\hline
\end{tabular}

Table (1) reveals the effect size of the overall test and the three components of the test. The $t$ value of the overall test is 47.69 which means that the test had a large size effect on developing the skills of the translation of documents in its three components.

From the above table, it was clear that the participants of the study had an improvement in the translation of certificates rather than the other two criteria, where the t value was 43.74 , and the effect size was 7.73 which is a great effect size. 


\section{Dr. Hanan Abdel-Baqi Mohammad Khalil}

\section{Hypothesis Two}

'There is a statistically significant difference between the mean scores of the experimental group in pre and post administrations of the attitudes questionnaire in favour of the postadministration of the questionnaire'

\section{Results of Attitude Questionnaire}

Table(6): The Difference between Pre / Post Administrations of the Attitudes Questionnaire

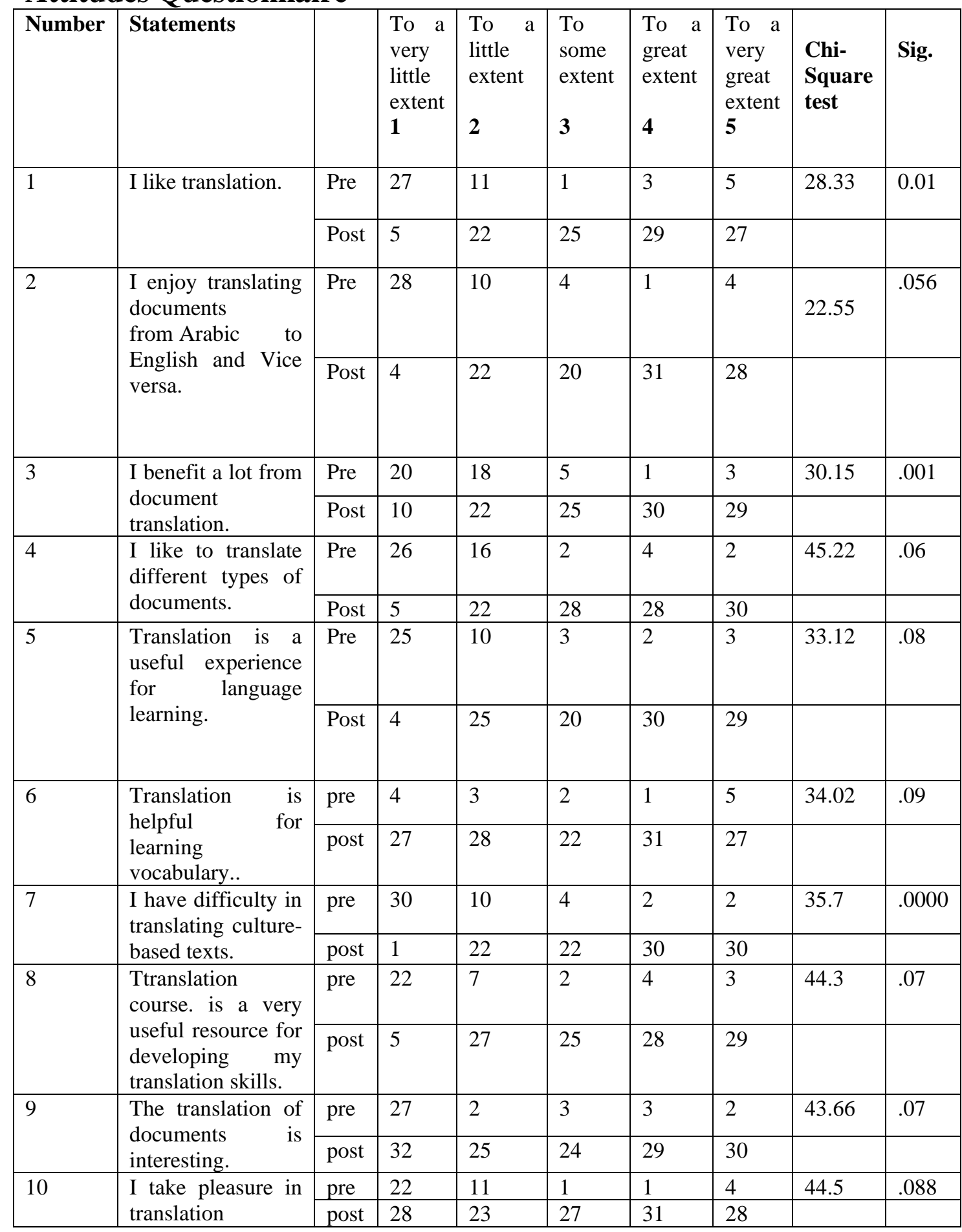


The Effect of a Training Program Based on Task-Based Learning on Developing English Majors' Skill of Document Translation and Their Attitudes towards Translation

Findings of the attitude questionnaire that was designed and used by the researcher at the

end of the program to the study group revealed that:

- All the participants in the program had positive attitudes towards translation in general and the translation of documents in specific after studying the training program.

- Most of the study group enjoyed studying in the training program, especially the group work.

- They could differentiate the various types of documents.

\section{Discussion of Results}

Thet test values and the effect size showed that there were statistical significant differences between the mean scores of the overall scores and the components; certificates, commercial contracts, and the legal documents of the pre/ post translation of documents test in favor of the post test of the study group.

This means that the students' skill of document translation achieved higher on the overall translation of documents after studying the training program based on Task Based learning in the translation of documents. Specifically, higher performance was achieved in the translation of different types of documents. This implies that the progress that occurred in the experimental group's translation of documents was due to the effectiveness of the training program based on TBL.

Furthermore, the statistical significant differences in favor of the post administration of the translation of documents test proved that employing the task-based instruction framework in the translation of documents classroom might have promoted the study group's understanding of the types of documents, the benefits of the translation of documents, the rationale of using tasks in teaching those types of translating documents.

The achievements of the study group in the three types of documents were high but there were slight differences among the three types of the documents. The students' achievements in translating certificates were slightly higher than those of the other two types; the commercial contracts , and the legal documents because this type of documents usually includes just fixed terminology and a few number of expressions to complete translating those certificates, the participants also used to participate in translating the certificates with their peers.

From a different perspective, their development in translating the commercial contracts improved because of their employing of tasks in dividing the contracts among the members of each group to complete the 


\section{Dr. Hanan Abdel-Baqi Mohammad Khalil}

translation of the contract had a large effect size reached to 5.68 and a $t$ value reached to 32.14. This means that using the task-based learning approach had a large effect on developing the translation of documents.

The translation of the legal documents had a large effect size reached to( 5.43), and a $t$ value reached to (30.75) which proved that the training program based on TBL was effective in developing the translation of legal documents.

Adopting the task based learning TBL proved to be successful to help the students to be able to explore successfully the importance of utilizing the fixed expressions of each type of documents, paying attention to using the appropriate linguistic context and putting into consideration the cultural background of the information included in each document. that is suitable for each type of documents.Results of the current study goes with the results of other studies such as those of (Nunan, 2004; Oxford, 2009;Beil, 2011;Darani, 2012)

- The training program based on TBL proved to have positive achievements on the English majors' skill of document translation who participated in the experiment for some reasons:

- Helping the study group to be in high spirits because of their continuous in the progress in translation the three target types of documents.

- English Majors became more self- confident because of acquiring the ability to accomplish their tasks successfully.

- Developing the spirit of team work among the study group through dividing the difficult tasks into sub-tasks to complete translating the whole document.

- Changing their attitude towards translation in general and the translation of documents in particular to be positive.

- Developing learning autonomy through translating the names of courses they study through individual activities using some search engines or online services available at MUST.

\section{Conclusion}

This study attempted to develop the skill of document translation through adopting training program based on Task- Based Learning and tasks needed for the translation of documents among $3^{\text {rd }} \& 4$ th year English majors at Misr University for Science and Technology (MUST).The findings of the current study have significant implications for learners, translators, and teacher educators in the field of TEFL in particular and researchers Instructors are advised to train their learners on how to use the tasks in helping their learners to be more efficient during the process of translating documents. Lectures of translators can help their learners to 
The Effect of a Training Program Based on Task-Based Learning on Developing English Majors' Skill of Document Translation and Their Attitudes towards Translation

be efficient translators. The process of translating documents especially the legal documents and the commercial contracts need a lot of training and dividing the activities as tasks especially among peers in the same classroom.

This study proved evidence for the benefits of training based on task -based learning in developing translation in general and the translation of documents in particular. The results of the current study proved that translation of documents could be enhanced through utilizing peer correction and the group work activities.

\section{Suggestions for Further Research}

- Further studies can be carried out in other types of translation, especially interpretation, consecutive translation, dubbing.

- Conducting other researches based on using other methods or approaches to develop translation (e.g. functionalism, Scopos theory, Beyond Constructivism, Lexicography, Corpus- Based Method)..

- Carrying out a study about the importance of both the cultural background and the awareness of linguistics, and their effect on translation from and to the Arabic language.

- Conducting a study on content analysis of the samples of answers in the secondary school stage students to improve their translation skills. 


\section{Dr. Hanan Abdel-Baqi Mohammad Khalil}

\section{References}

Al -Aqad, M. H. (2014). Translation of Legal Texts between Arabic and English: Case Study of Marriage Contracts. Arab World English Journal 5(2), 110-121.

Al-Kholy, A. S.(2013). A legal Linguistic Analysis of Arabic into English: A contrastive Stylistic Approach (Unpublished MA thesis). Ain Shams University, Cairo, Egypt.

Al Morshedy, M. M. (2007). Translation of Commercial Contracts.

Dar El-Gamaa Publishers, Alexandria, Egypt.

Biel, L, (2009).Organization of Background Knowledge Structures in legal language and Related Translation Problems. International Journal of Legal Communication, 2,176-189.

Biel, L. (2011). Professional Realism in the Legal Translation Classroom: Translation Competence and Translator Competence. Translators' Journal, 56(1), 162-178.

Brunham,S. J. (2003). Drafting and Analyzing Contracts: A Guide to the practical Application of the Principles of Contract Law ( $3^{\text {rd }}$ ed).Newark, NJ: LexisNexis

Cao, D. (2007).Translating law (Topics in Translation). Toronto, Canada: Mutiligual Matters. Ltd

Cao, D. (2014).Teaching and Learning Legal Translation. Semiotica,201,103-119.

El-Farahaty,H. (2016). Translating Lexical Legal Terms between English and Arabic.

Int J Semiot Law, 29, 473-493

Ellis, R. (2009). Task-Based Language Teaching: Sorting out the Misunderstandings. International Journal of Applied Linguistics, 19(3), 221-246.

Ellis, R. (2013). Task-Based Language Teaching: Responding to the critics.

- University of Sydney Papers in TESOL, 8, 1-27.

- El Saeed, M. A. (2015). The Effect of Using Task-Based Learning Approach

- on Developing University Student-Teachers' Performance in Teaching the English. Unpublished $\mathrm{PhD}$ Thesis, Ain Shams University, Egypt.

- Galan-Manas, A. (2013). Contrastive Rhetoric in Teaching How to Translate Legal Texts. Perspectives: Studies in Translatology, 21 (3).

- Gotti, M. (2016). The Translation of Legal Texts: Interlinguistic and Interlinguistic Perspectives. Journal of English for Specific Purposes at Teratiary Level (ESP today), 4 (1), 5-21. 
- Hatim, B. C.; Shunnaq, A.; Buckley, R. (1995). The Legal Translation at Work: Arabic-English Legal Translation, A Practical Guide. Dar Al- Hilal for Translation and Publishing.

- Kabesh, M (2010). The Effectiveness of a Task-Based Learning Strategy on Developing Primary Students' Reading Comprehension and Writing Skills in Light of the Multiple Intelligence Theory.

$\mathrm{PhD}$ Thesis, Ain Shams University.

- Kasap, B (2005). The Effectiveness of Task-Based Instruction on the Improvement of Learners' Speaking Skills. An MA Thesis, Bilkent University.

- Kavaliauskiene, G (2005). Task- Based Learning and Learning Outcomes in the ESP classroom. Studies about language, 1(7), 1-6.

- Kavaliauskiene, G. (2005). Task-based Learning and Learning Outcomes in the ESP Classroom. Studies about Language, 1 (7), 106.

- Klapper, J (2003). Taking Communication to task? A critical review ofrecent trends in language teaching. Language learning journal, 27, $33-42$.

- Lee, J (2000). Tasks and Communicating in language classrooms. Boston:MC Graw-Hill.

- Liu, X \& Liu, Y (2011). Research on Developing Vocational College Students' Creativity Based on Tsk -Based Teaching Method. Asian Social Science vol.7, No 1, January 2011,www.ccsenet.org/ass.

- Maltulewska, A. ;Michalak,K. ( 2014). Teaching Certified Translator

- Candidates at the Adam Mickiewicz University Poznan, Poland.

- Proceedings from the International Conference: New Tasks for

- Legal Interpreters and Translators in the Enlarged Europe, 246-257.

- Martin, C. (2015).Task-Based Learning in the L2 Classroom.

- Retrieved from:

- http://www.westpoint.edu/cfe/Literature/Martin \% 2015.pdf

- MC Laughlin, J (2001). A Task Based Program in Korea: A Case analysis

- SLLT, vol. 1 (1), Oct .2001. Retrieved from:

- http://www.google.com

- . McAuliffe, K. (2016). Hidden Translators: The Invisibility of Translators and the Influence of Lawyer-Linguists on the Case Law of the Court of Justice of the European Union. Journal of language and Law ,3(1), 5-29.

- Murad, T (2009). The Effect of Task Based Language Teaching on Developing Speaking Skills among the Palestinian Secondary EFL students in Israel and their attitudes towards English._PHD Dissertation. Yarmouk University, 


\section{Dr. Hanan Abdel-Baqi Mohammad Khalil}

- Irbid, Jordan

- McBien, L.; Brandt, R. (2007). ASCO Lexicon of Learning: What Educators mean

- when they say. The Association for Supervisors and

- Curriculum Development, USA.

- Noman, F. F. (2014). A Register Analysis of the Constitution of the United

- States of America and its Arabic Translation (Unpublished MA thesis).

- Ain Shams University, Cairo, Egypt.

- Nunan, D. (2004). Task-Based Language Teaching. Cambridge : Cambridge

- university Press.

- Nunan, D (2005). Important Tasks of English Education: Asia-wide and beyond.

- Asian EFL Journal, 7 (1).

- Nunan, D. (2006). Task-Based Language Teaching in the Asia Context:

- Defining 'Task'. Proceedings of Special Conference: Task-Based Learning

- in the Asian Context. The Asian EFL Journal Quarterly, 8(3), 12-18

- Nunan, D. (2006). Designing Holistic Units for Task-Based Learning.

- Proceedings of Special Conference: Task-Based Learning

- in the Asian Context. The Asian EFL Journal Quarterly, 8(3), 69-93.

- Orts LIopis, A. (2009). Legal Genres in English and Spanish: Some Attempts

- of Analysis. IBERICA, 18, 109-130.

- Oxford, R (2006). Task Based Language Teaching and Learning: An overview.

- Asian EFL Journal, 8 (3), 94-121. Retrieved from:

- http://www.asian-efl-journal.com/septo6ro.php.

- Pryal, K. G. : Jack, J. J (2010). The Legal Writing Workshop: Better Writing. One Case at a Time ( $\left.2^{\text {nd }} \mathrm{ed}\right)$. North Carolina, NC: Research Triangle International.

- Ruso, N (2007). The influence of task based learning on EFL classroom.

- Asian EFL Journal, 2 (11).

- Salimi, A. (2015). The Effect of Focus on Form and Task Complexity on L 2 Written Accuracy. Theory and Practice in Language Studies, 2 (11), 2398-2406. 
- Sandrini, P. (2009). The Parametres of Multilingual Legal Communication in a Glopalized World. International Journal for Legal Communication 2(34-48).

- Sarcevic, S. (2001). Legal Translation: Preparation for Accession to the European Union. Rijeca, Croatia: University of Rijeca,

- Snachez, R. (2004). The Tsk- Based Approach in Language Teaching.

- International Journal of English studies, Vol. 4(1), 2004.Pp. 39-71 University of Murcia.

- Stolze, R. (2013). The Legal Translator's Approach to texts. Humanities, 2, 56-71.

- Swan, M (2005). Legislation by hypothesis: The Case of Task- Based Instruction. Applied linguistics 26/3: 376- 401. Oxford University press.

- Telebia, A.S. (2004). A Suggested Programme for Developing Some Basic Translation Skills of English Majors and its Effect on their Attitudes towards Translation( Unpublished PhD Dissertation).SouthValley University, Qena, Egypt.

- Webster, M.(2016). Webster's New Collegiate Dictionary. Merriam Webster INC, Springfield, Massachusetts, USA.

- Willis, J. R. (1996). A Framework for Task-Based Teaching. Oxford: Oxford University Press.

- Willis, J (2001). A Framework for Task Based Learning. Addison Wesley Longman.

- Zedan, A. A. (2015). A Linguistic Analysis of Some Problems of Arabic-English Translation of legal Texts, with Special Reference to Contracts. Newcastle upon Tyne, UK: Cambridge Scholars Publishing. 